\title{
Review \\ Ecology of Ixodes pacificus Ticks and Associated Pathogens in the Western United States
}

\author{
Molly McVicar ${ }^{+}{ }^{(D}$, Isabella Rivera ${ }^{\dagger}$, Jeremiah B. Reyes ${ }^{(D)}$ and Monika Gulia-Nuss *(D)
}

check for updates

Citation: McVicar, M.; Rivera, I.; Reyes, J.B.; Gulia-Nuss, M. Ecology of Ixodes pacificus Ticks and

Associated Pathogens in the Western United States. Pathogens 2022, 11, 89. https://doi.org/10.3390/pathogens 11010089

Academic Editor: Lawrence S. Young

Received: 16 November 2021

Accepted: 10 January 2022

Published: 13 January 2022

Publisher's Note: MDPI stays neutral with regard to jurisdictional claims in published maps and institutional affiliations.

Copyright: (C) 2022 by the authors. Licensee MDPI, Basel, Switzerland. This article is an open access article distributed under the terms and conditions of the Creative Commons Attribution (CC BY) license (https:// creativecommons.org/licenses/by/ $4.0 /)$.
Department of Biochemistry and Molecular Biology, University of Nevada, Reno, NV 89557, USA; mmcvicar@nevada.unr.edu (M.M.); bellarivera2021@gmail.com (I.R.); jeremiahbreyes@nevada.unr.edu (J.B.R.)

* Correspondence: mgulianuss@unr.edu

+ These authors contributed equally to this work.

\begin{abstract}
Lyme disease is the most important vector-borne disease in the United States and is increasing in incidence and geographic range. In the Pacific west, the western black-legged tick, Ixodes pacificus Cooley and Kohls, 1943 is an important vector of the causative agent of Lyme disease, the spirochete, Borrelia burgdorferi. Ixodes pacificus life cycle is expected to be more than a year long, and all three stages (larva, nymph, and adult) overlap in spring. The optimal habitat consists of forest cover, cooler temperatures, and annual precipitation in the range of $200-500 \mathrm{~mm}$. Therefore, the coastal areas of California, Oregon, and Washington are well suited for these ticks. Immature stages commonly parasitize Western fence lizards (Sceloporus occidentalis) and gray squirrels (Sciurus griseus), while adults often feed on deer mice (Peromyscus maniculatus) and black-tailed deer (Odocoileus h. columbianus). Ixodes pacificus carry several pathogens of human significance, such as Borrelia burgdorferi, Bartonella, and Rickettsiales. These pathogens are maintained in the environment by many hosts, including small mammals, birds, livestock, and domestic animals. Although a great deal of work has been carried out on Ixodes ticks and the pathogens they transmit, understanding I. pacificus ecology outside California still lags. Additionally, the dynamic vector-host-pathogen system means that new factors will continue to arise and shift the epidemiological patterns within specific areas. Here, we review the ecology of I. pacificus and the pathogens this tick is known to carry to identify gaps in our knowledge.
\end{abstract}

Keywords: ticks; Ixodes; Ixodes pacificus; tick-borne pathogens; tick ecology; Lyme borreliosis

\section{Introduction}

In recent decades, an increase in the emergence rate of vector-borne zoonotic diseases has presented new challenges and threats to public health [1,2]. Several factors, including land use and climate change, contribute to the increase in these infectious zoonotic diseases. Climate change has expanded the range of vector species, bringing them closer to the human populations and altering vector-borne disease dynamics [3]. For instance, an increase in wildfire numbers and intensity in the Western USA has been predicted to increase the movement of large ungulates that may carry ticks to new areas and establish vector populations [4]. Similarly, new pathogens might be associated with changing host ecology and may also alter human disease risk through infection prevalence with pathogens $[5,6]$.

Lyme disease is the most important vector-borne disease in the United States [7]. Lyme disease is caused by an infection with the spirochete, Borrelia burgdorferi, transmitted to humans mainly by black-legged ticks. In the eastern and north-central United States, Ixodes scapularis Say, 1821 is the primary vector of B. burgdorferi and also transmits B. miyamotoi, Anaplasma phagocytophilum, and Babesia microti [8]. In the western United States, I. pacificus is the primary vector of these pathogens [9-11].

Ixodes ticks are three-host ticks. Each developmental stage (larvae, nymph, and adults) has a different seasonal activity and feeds on different hosts. While some Borrelia species 
such as B. miyamotoi can be transovarially transmitted, B. burgdorferi cannot but can be acquired by ticks either through blood meals from infected hosts or transstadially [12-16]. Humans are accidental hosts and acquire tick bites, usually during outdoor recreational activities. The nymphal stage is critical for human infections because larvae are usually uninfected and acquire pathogens during blood feeding, resulting in transstadially infected nymphs. Nymphs typically go unnoticed by unsuspecting humans due to their small size and shorter feeding periods than adults (approximately five days vs. 8-10 days of the adult) [17]. Seasonal activity and density of potentially infectious tick life stages are thus critical components for tickborne disease risk assessment.

In the western United States, especially in California, where most studies have been conducted, both tick vectors and the Borrelia spirochetes species have a greater diversity [18] compared to the eastern United States. Up to 20 different Ixodes species have been reported in California. However, only I. pacificus is considered the primary vector of $B$. burgdorferi because it commonly bites humans and thus serves as a major bridging vector of B. burgdorferi [19]. The other endemic species which preferentially feed on rodents include I. spinipalpis, I. angustus, I. neotomae, and I. jellisoni [20]. The passive surveillance suggested that conventionally recognized non-human feeders (I. spinipalpis and I. angustus) occasionally parasitize humans [21], suggesting a more complex disease transmission cycle in this region.

Currently, only four Borrelia species within B. burgdorferi sensu lato (s. l.) have been found in the northeastern and upper midwestern United States: B. andersonii, B. burgdorferi sensu stricto (s. s.), B. kurtenbachii, and B. mayonii, with B. burgdorferi s. s. representing the dominant species [22,23], whereas, in addition to B. burgdorferi s. $s$, several species within the B. burgdorferi s. l. complex, including B. americana [24], B. bissettiae [25], B. californensis [26], and B. lanei [27] have been found in the western United States. However, B. burgdorferi s. s. is the only species associated with Lyme disease [18].

The prevalence and ecology of Lyme disease in the western United States differ significantly from that in the northeastern and midwestern United States. The overall incidence of Lyme disease in the western United States is 0.2 cases compared to up to 80 cases per 100,000 persons per year in the northeastern and upper midwestern United States [28]. In the Northeast, B. burgdorferi is primarily maintained in white-footed mice (Peromyscus leucopus) by I. scapularis [29]. However, in the west, white-footed mice have a low tick load and low prevalence of B. burgdorferi [20]. In contrast, the western gray squirrel (Sciurus griseus) and dusky-footed woodrat (Neotoma fuscipes) appear to be the predominant reservoir hosts of B. burgdorferi [30-32].

This review aims to provide a broad overview of the abiotic and biotic factors that influence the distribution and abundance of I. pacificus and the transmission dynamics of tickborne pathogens.

\section{Habitat}

In the United States, the I. pacificus range includes most of the coastal areas of California, Oregon, and Washington, with a few reports from northwestern Utah and Southern Nevada [33]. However, the full range is from British Columbia, Canada, in the North to Mexico in the South. Ixodes pacificus is broadly distributed across California [34-37] and has been collected in 56 of 58 counties [11,31,34,38,39] (Figure 1). The ideal temperature for adult I. pacificus ranges from 0 to $20^{\circ} \mathrm{C}$ and ideal precipitation between 300 and $600 \mathrm{~mm}$ per year; however, habitat suitability increases at precipitation between 200 and $500 \mathrm{~mm}$. A minimum of $40 \%$ forest cover and low elevation (sea-level) have been reported as ideal for this species. However, this varies between locations, and I. pacificus has been collected from elevation up to $2200 \mathrm{~m}$ in northeastern California and Utah [33]. 


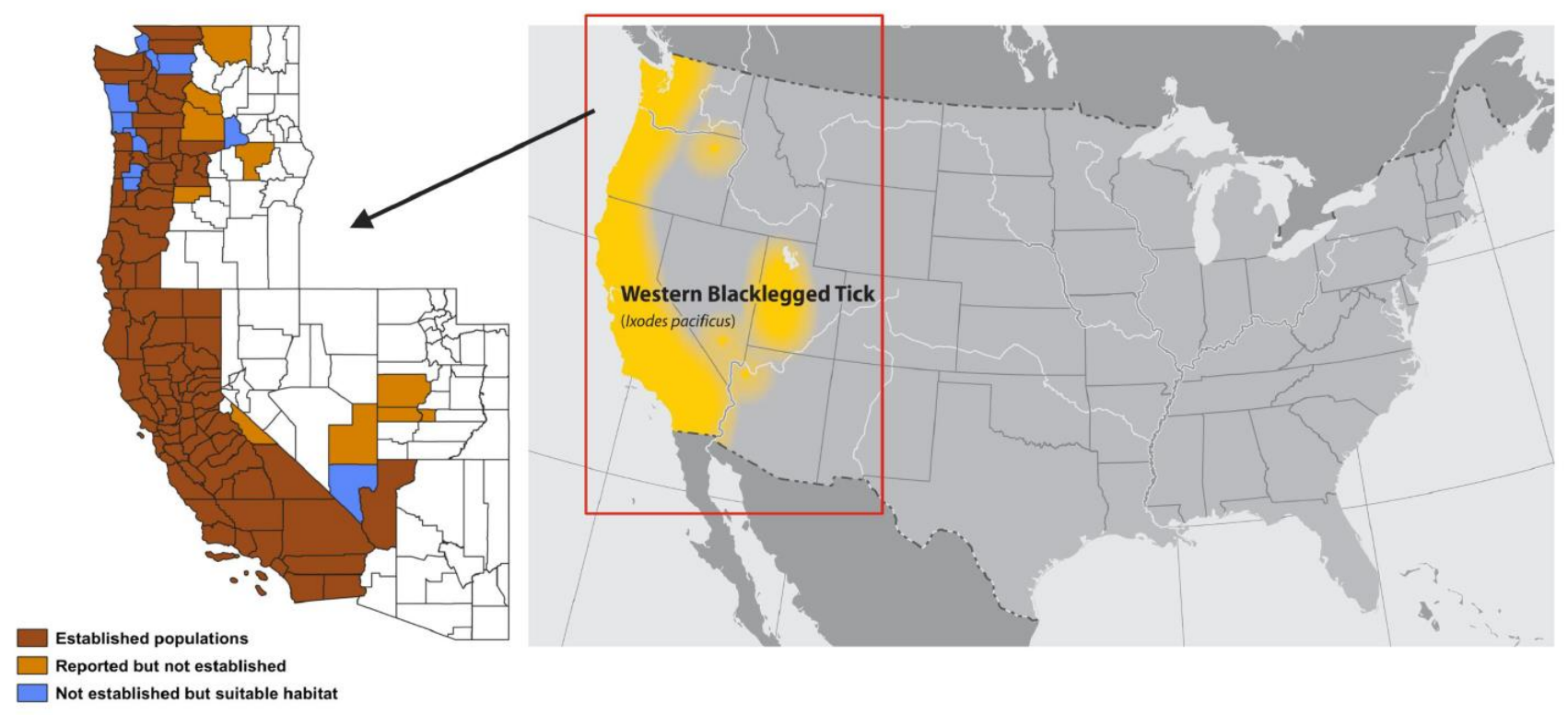

Figure 1. Map of the USA and the Pacific region depicting counties where I. pacificus populations are either established, reported, or predicted as suitable by modelling. The yellow color on the US map depicts I. pacificus range. Counties in brown have established I. pacificus populations. Counties in orange have reported but not established I. pacificus populations. Counties in blue do not have an established I. pacificus population but are predicted to have suitable habitat by two or more ensemble model members. The USA map was downloaded from the Centers for Disease Control and Prevention website. Background data for this map is adapted from the US National Atlas and published on the National Center for Emerging and Zoonotic Infectious Diseases, Division of Vector-borne diseases. County map is adapted from [33] and Centers for Disease Control and Prevention. Image developed in Biorender.

The microclimate, such as the local temperature, wind speed, degree of exposure, soil moisture, tree cover, the direction of the sun, and saturation deficit, can influence tick habitat. The shielded habitats with tree canopy, leaf litter layer, or undergrowth and shrub cover provide a constant microclimate. Dense oak woodlands are the preferred habitat of I. pacificus in California. Significantly more ticks were found on trunks of moss-covered oak trees within woodland grass habitats as moss reduces surface temperatures of the tree by an average of $1.9{ }^{\circ} \mathrm{C}$ and increases relative humidity ( $\mathrm{RH}$ ) by up to $2.5 \%$ [40]. An average of 1.06 ticks was found on all oak trees in northern California, specifically along the coast of Mendocino County; 1.05 ticks on all trees with basal leaf litter, and 1.19 ticks for trees of large circumference were reported [40] supporting the idea that microclimate is important factor for tick abundance.

MacDonald et al. chose three diverse sites in Santa Barbara County, CA, to collect I. pacificus ticks weekly from November to June 2013 to 2015. These sites were (1) Coal Oil Point Reserve, a habitat taken over by coastal scrub, grassland, and patches of Coast Live Oak; (2) Paradise Reserve, a habitat dominated by oak woodland with patches of open grassland and interspersed chaparral and scrub; and (3) Sedgwick Reserve, a habitat overrun by oak woodland on northern facing slopes, Oak Savannah in the valleys, and grasslands, chaparral, and scrub [41]. Each site also had varying climates. Coal Oil Point Reserve has a clear marine influence moderating temperatures and providing water subsidies; Sedwick Reserve experiences generally warmer summers and colder winters than the other two sites; Paradise Reserve experiences lower temperature extremes than the other sites Sedgwick Reserve [41]. At Coal Oil Point Reserve, only adult I. pacificus ticks were collected. In contrast, at Paradise Reserve and Sedgwick Reserve, all three life stages were collected [41], suggesting that all these habitats are suitable for I. pacificus. 
Nymphal I. pacificus were collected from picnic areas at a similar proportion to leaf litter. In addition, the wooden picnic tables and other wood items, such as tree trunks and logs, also carry I. pacificus [42], suggesting that the risk of encountering nymphs around wooded areas is similar to that in leaf litter.

In Utah, Davis et al. surveyed 175 sites and collected 119 I. pacificus ticks from six locations between 1700 and $2200 \mathrm{~m}$ elevations. Over $90 \%$ of the total ticks in Utah were from the Sheeprock Mountains in Tooele County, the habitat characterized by Gambel Oaks, Junipers, Big sagebrushes, Black sagebrushes, and mixed grass [43]. All ticks were collected when daytime temperatures ranging between 6.0 and $29.0^{\circ} \mathrm{C}$ [43].

\section{Tick Distribution}

To accurately record I. pacificus distributions, a county classification guideline was developed. According to these guidelines, counties may be classified as "established" if either six ticks or two or more life stages are collected in a single year. It is classified as "reported" if the tick collections fail to meet the abovementioned thresholds [11,33]. Ixodes pacificus distribution models suggest a potential expansion along the Oregon-Washington border and suitable habitats in 11 additional counties, representing a $12 \%$ possible increase in established counties [33] (Figure 1).

In 1998, populations of I. pacificus ticks were established in 95 counties in six states, 56 of those counties in California [11], a total of 3.6\% of all US counties, whereas these ticks were reported in additional 16 counties (total of 111). Much of the distribution has been on the coast, where the humidity and temperature are higher than the inland [38]. However, the range is slowly expanding [38]. Specifically, the reported I. pacificus ticks in Washington were up from five counties in 1998 to six counties in 2015 and established status in Washington increased from 12 in 1996 to 16 counties in 2015 [11]. In total, five counties (Toole, UT; Cowlitz, WA; King, WA; Kitsap, WA; Clallam, WA) now have established population instead of reported or no records, and an additional four counties have reached recorded status for I. pacificus (Kittitas, WA; Okanogan, WA; Pacific, WA; Yakima, WA) [11]. Overall ratios of counties classified as "established" versus "reported" increased from 5.1:6 in 1998 to 5.94:1 in 2016, suggesting a modest expansion of I. pacificus ticks in western states [11].

The overall abundance of I. pacificus ticks in Utah, Oregon, and Washington appears to be low compared to California; however, more work is needed. A distribution map of 2332 I. pacificus ticks submitted by Citizen Science Tick Collections from 2016 to 2018 was developed. Out of these 2332 ticks, 54 were from Oregon, 26 were from Washington, and the remaining were collected over 397 Californian sites [44]. In a recent citizen science study [44], 2525 I. pacificus ticks (majority adults) were submitted to the Bay Area Lyme Organization and the Arizona State University from 87 counties in California, Oregon, and Washington [44], suggesting higher prevalence in the coastal states. Data collected from other western states is scarce compared to California; increased efforts in tick collections are needed to accurately assess tick distribution in these states.

\section{Hosts}

Access to suitable hosts is critical for the development and survival of ticks. Ixodes pacificus feed on a wide range of hosts such as mammals, birds, and reptiles (Table 1). Different host species are preferred depending on the life stage of the tick [45]. The western fence lizard, Sceloporus occidentalis, and the southern alligator lizard, Elgaria multicarinata, are the most common hosts for immature stages (both larvae and nymphs) of I. pacificus. A total of 52 lizards were captured and examined; 162 I. pacificus ticks were collected from 8 Southern alligator lizards with larvae to nymph ratio of 3:2; 22 Western fence lizards infested by 323 I. pacificus ticks with larvae to nymph ratio of 2:3; 22 Western skinks infested by 35 I. pacificus ticks with larvae to nymph ratio of 4:1 [46]. In another study, the western fence lizard accounted for $78 \%$ of larval and $98 \%$ of nymphal feedings in chaparral in Mendocino County, CA [47], highlighting the importance of lizards as hosts to I. pacificus 
immatures. Eisen et al. suggested that in Mendocino County, CA, immature I. pacificus fed significantly on western fence lizards and western gray squirrels (9-35 larvae and 5-6 nymphs per animal). The number of ticks feeding on lizards and squirrels was far greater than that feeding on woodrats, mice, and birds (0.9-3.5 larvae and 0-0.3 nymphs per animal) [48]. Several species of rodents including the dusky-footed woodrat (Neotoma fuscipes), the California kangaroo rat (Dipodomys californicus), the brush mouse (Peromyscus boylii), the deer mouse (P. maniculatus), and the pinyon mouse (P. truei) have also been shown as I. pacificus hosts. The average number of immatures feeding on birds and rodents, 2.9 and 1.3 of 204, respectively, remained low [46]. Out of 182 mammals inspected, three species of rodents (pinyon mouse, brush mouse, and dusky footed woodrat) were infested almost exclusively with larval I. pacificus ticks. The deer mouse, Peromyscus maniculatus, and Columbian black-tail deer, Odocoileus $h$. columbianus, served as common hosts for adults [46].

Table 1. Hosts associated with Ixodes pacificus life stages. These data are adapted from [45] and a full list with species names is provided in the publication [45].

\begin{tabular}{cccc}
\hline Ixodes pacificus Life Stage & \multicolumn{3}{c}{ Preferred Hosts } \\
\hline & Mammals & Birds & Reptiles \\
\hline Larvae & 29 & 43 & 8 \\
\hline Nymphs & 30 & 38 & 8 \\
\hline Adults & 29 & 2 & 1 \\
\hline
\end{tabular}

Ground-dwelling birds were also common hosts for immature stages in Northern California [45]. Birds found in tick-questing substrates such as leaf litter had higher infestation by I. pacificus immature stages (5.2 larvae and 1.0 nymph per bird) than birds that did not utilize or visit leaf litter [48]. A total of 222 birds were collected by Wright et al. and included 19 species, 7 of which (Western tanager, brown-headed cowbird, Cassin's Vireo, hermit thrush, Pacific-slope flycatcher, acorn woodpecker, and pileated woodpecker) had no ticks [46]. However, the remaining 12 species were infested with I. pacificus. Nine species (the Oregon junco, California towhee, spotted towhee, purple finch, black-headed grosbeak, orange-crowned warbler, house wren, brown creeper, and oak titmouse) were infested with both larval and nymphal ticks (Table 1).

Interestingly, American robins and Hutton's vireo were only infested by nymphal ticks, and one species, lesser goldfinch, had only larval ticks [46]. Hutton's vireo typically forages high up in trees and is not a common host for ticks. In contrast, the lesser goldfinch forages in densely foliaged trees and shrubs, dry streambeds, and fields and pastures. Chaparral and coastal sage scrub-laden hillsides, including black and white sage, are some of the typical habitats of lesser goldfinch, making it a more suitable host for larval ticks. Bird species that tend to forage in leaf litter or nest on the ground, such as Oregon juncos, Orange-crowned warblers, House wrens, California towhees, and Spotted towhees, were infested with thrice as many larvae than nymphs [46]. In contrast, bird species that foraged on tree bark or canopies such as brown creepers, black-headed grosbeaks, purple finches, and oak titmouse were infested with three times more nymphs than larvae [46].

Host-seeking behaviors also vary based on location and time of the year. In California, I. pacificus populations from the northern and southern parts differ in the times in which they are active. In northern California, larvae and nymphs host-seek from mid-March through late June [49]. In southern California, they start and cease host-seeking earlier, between late February through mid-May and early June [39]. Adult ticks typically engage in host-seeking from November to early May in northern and coastal California. In southern California, host-seeking starts in December and ends by May (Figure 2) [50]. These monthly predictions rely on vegetation, precipitation, and maximum temperature and differ slightly from season to season. While adults are often found ascending vegetation to seek hosts, 
nymphs and larvae rarely do. Therefore, brushing against the vegetation during outdoor activities leads to the attachment of adult ticks to humans.

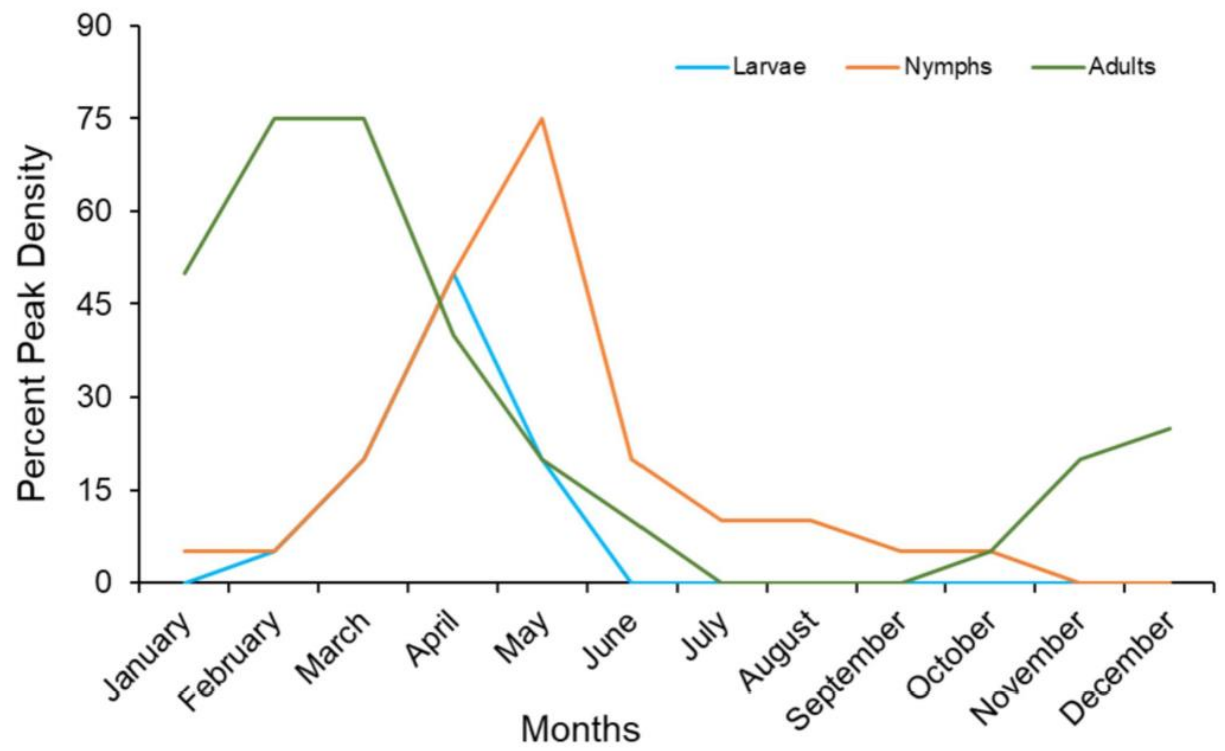

Figure 2. Seasonal density of I. pacificus life stages in California. Based on the literature searches, seasonal density was plotted for all three life stages. The numbers are approximation based on all data available on seasonal variations.

\section{Life Cycle}

The lifecycle of I. pacificus ticks was closely studied over two decades ago, including oviposition and larval hatching [51]. Replete females were held in individual containers at temperatures ranging between 9 and $29^{\circ} \mathrm{C}$ for egg-laying. Females deposited eggs at an average of 9-70 days after drop-off [51]. Egg masses held between 12 and $25^{\circ} \mathrm{C}$ hatched approximately 25-178 days after oviposition, while at 9 or $29^{\circ} \mathrm{C}$ failed to hatch [51]. The investigators determined that lower temperature thresholds for development, oviposition, and hatching were 6.5 and $9^{\circ} \mathrm{C}$, respectively [51]. During December through March, females collected from Tilden Regional Park in Berkeley, CA, were placed into three habitats (mixed annual grasses, Coyote brush, and grassy slope in between) at the University of California Berkeley Field Station for behavioral research. Berkeley experiences temperature ranges from -1 to $21{ }^{\circ} \mathrm{C}$ in winters and 7 to $26{ }^{\circ} \mathrm{C}$ in summers. Eggs were deposited between early February and late April, and larvae hatched between early July and late August [51]. The ticks placed in the Coyote brush hatched at an average of 122-158 days following oviposition, while ticks placed in exposed habitats hatched at an average of 130-160 days [51]. Notably, hatching success was lower for eggs deposited in the grassy slope (29\%) compared to eggs deposited in the Coyote brush (87\%) [51]. All I. pacificus larvae from eggs deposited in grassy or exposed habitats died within two weeks of hatching, while all larvae from eggs deposited in brush habitats reported no significant death rates [51]. Of the hatched eggs within the Coyote brush, unfed larvae from 2 of 20 egg masses managed to survive through the winter. They fed readily in late April and then molted throughout August, suggesting that survival during the dry autumn due to brush shelter aided in longer lifespans [51]. Padgett and Lane suggested that I. pacificus required more than one year to complete a life cycle that was later confirmed [52].

\section{Environmental and Climate Factors Associated with Survival}

Understanding abiotic and biotic factors and how they may impact the activity, development, and density of I. pacificus ticks in specific areas are some of the most complex information to gather. In laboratory studies, the optimum molting rate for I. pacificus ticks appears to be $21^{\circ} \mathrm{C}$. A negative correlation was recorded between maximum temperatures 
and the density of I. pacificus nymphs in Sonoma County, California, in 2007, but not in 2006 [53]. Despite this evidence, Swei et al. concluded that habitat variables indirectly affect the relationship between I. pacificus tick density and maximum temperatures [53]. $50-75 \%$ of nymphal peaks were positively correlated with rainfall and negatively correlated with maximum air temperatures during April and May [54]. Ixodes pacificus ticks that were collected from cooler/moister redwood sites, compared to warm/dry oak woodland sites, typically reached $50 \%$ of their peak $10-15$ days later, remained at $50 \%$ of their peak 1.3-1.5 times longer, and started declining 4-6 weeks later [54]. Together, these results suggest that $I$. pacificus nymphal density starts to decline at temperatures between 21 and $23{ }^{\circ} \mathrm{C}$ and at an average maximum daily relative humidity $(\mathrm{RH})$ below $83-85 \%$ [54].

Areas in California that experience warm and wet winters are reportedly most suitable for I. pacificus ticks. More specifically, suitability for I. pacificus ticks increases between 0 and $400 \mathrm{~mm}$ of cold-season precipitation, a plateau between 400 and $800 \mathrm{~mm}$, and decreases when rainfall exceeds $800 \mathrm{~mm}$. Therefore, the most suitable areas are the ones that receive moderate amounts of cold-season precipitation. In contrast, the least suitable areas are drier or high precipitation regions [55]. Excessive heat between 32 and $40{ }^{\circ} \mathrm{C}$ increases rates of tick mortality and decreases rates of successful reproduction [55]. MacDonald et al. suggested that high rainfall may inhibit or reduce host-seeking activity for all life stages. In contrast, high humidity allows for longer intensive host-seeking activity while expending less energy [56]. The same study concluded that hot and dry regions with increasing temperatures are less suitable while wet and cooler areas are better suited for I. pacificus survival [56].

The survival rates of immature I. pacificus ticks were studied utilizing one laboratory setting and two field sites in northern California: Sonoma County and Quail Ridge Reserve. In all three locations, the survival of larval and nymphal ticks ranged from 90 to 400 days [47]. Relative humidity was at its lowest during the summer seasons in Quail Ridge (74.9\%) and Sonoma (76.0\%). Although RH remained higher in Sonoma than in Quail ridge, the temperature was higher in Quail Ridge than in Sonoma (21.6 vs. $\left.20.1^{\circ} \mathrm{C}\right)$ [47]. The same pattern was also observed in the winter season [47]. The first purge of ticks occurred at all sites at an $\mathrm{RH}$ increase from 80 to $100 \%$ and a temperature decrease from 22 to $15^{\circ} \mathrm{C}$; however, the purge also happened within the laboratory setting where temperature and $\mathrm{RH}$ ranges remained constant at $22.5-22.9^{\circ} \mathrm{C}$ and $70-70.7 \%$, respectively. Thus, fewer I. pacificus ticks died at this point within the field than in the controlled setting, and the ticks at Quail Ridge had an overall lower mortality rate than ticks in Sonoma [47]. Although $\mathrm{RH}$ remained higher in Sonoma, it might have led ticks to be more active, expending their energy quicker than ticks in Quail Ridge, resulting in decreased survival.

The effects of wildfires on I. pacificus populations in California have also been studied to some extent. Increased abundance of questing adult and nymphal I. pacificus was reported in the year following a fire and a decrease after that, possibly due to adverse effects on the microclimates caused by the fire [57]. However, another study [58] found no significant change in tick abundance following a wildfire. This vital question remains open as wildfire season increases in duration and overlaps with I. pacificus questing season.

\section{Seasonal Density}

Seasonal density can be considered crucial when comprehending the risks regarding concentrated numbers of I. pacificus ticks in a specific area. The earliest credible data were acquired over four years from 1998 to 2001 in Mendocino County, California [49]. The nymphal peak reached 50\% from early to mid-April in studies from 1998 to 2001, with the average maximum daily air temperature between 15 and $20.5^{\circ} \mathrm{C}$ [49]. Nymphal activity exceeding $50-75 \%$ of peak densities was positively correlated to rainfall from April to May [49] (Figure 2). Nymphal tick activity started declining at an average temperature of $21^{\circ} \mathrm{C}$. During the initial 20 days of nymphal tick decline, average temperatures were between 23.0 and $28.0{ }^{\circ} \mathrm{C}$ during the study period of 1998-2001 [49]. However, the au- 
thors concluded that no direct correlations between the rate of decline and temperature were found.

In California from 2012 to 2015, the first I. pacificus larvae activity was observed at Sedgwick Reserve in late February, and larvae were absent by mid-May. At Paradise Reserve, larvae were first observed in early March and absent by mid-May, and at Stunt Ranch Reserve, first observed during early to late February and absent by early to late May [39]. Similarly, in Santa Barbara County, CA, larvae were active between March and May, with minimal activity during late January and February [59] (Figure 2).

A number of studies suggest that I. pacificus nymphs typically become active in early to late February and reach $50 \%$ of their yearly peak density in early- to mid-April $[39,49]$. Nymphs typically peaked by early May, fell below $50 \%$ of their peak densities by early- to mid-June, and were absent by mid-August $[39,49,59]$. Interestingly, nymphs in Sonoma County remained active from May through August and were found as late as October [31]. From 2012 to 2015, initial nymph activity was observed at Sedgwick Reserve in late February and was absent by mid-April. At Paradise Reserve, nymphs were observed in early March and were absent by mid-May, while at Stunt Ranch Reserve first activity was in early March and remained active through early June [39]. Using a "Week" model, Eisen et al. (2017) could predict the probability of elevated nymphal densities with great accuracy using calendar weeks. They predicted an overall span of 23 weeks with elevated nymphal density with an increase as early as week 8.9 (late February), continuous increase until week 20.4 (mid-late May). Density decreases below "elevated" thresholds by the week of 31.9 (early August) [60] (Figure 2).

Ixodes pacificus adults typically become active during late October and early November and are usually reported after the first rainfall or snow of the season [31]. Following their peak in January, the density of adult ticks decreases and is absent by June and July [31]. When the first adults appeared in mid-December, the peak shifted to February and March [39]. In another study in Santa Barbara County, adult activity was observed between November and December until early June [59]. The seasonal pattern suggests that different stages of I. pacificus are active year-round. Because most pathogens are acquired by the ticks transstadially, infected ticks (nymphs and adults) could be present year-round and pose a health risk to humans. Therefore, personal protective measures, as discussed later in this review, must be taken all year around.

\section{Infection Prevalence in Ixodes pacificus}

\subsection{Babesia Species}

Babesia is a genus of intraerythrocytic parasites commonly known as the causative agents of human and animal babesiosis. Ixodes scapularis ticks transmit Babesia spp. [61], whereas I. pacificus ticks are predicted to be vectors for this pathogen, but it has not been experimentally confirmed as of yet. In a single study that collected adults and nymphs of I. pacificus from multiple sites in California, 3.0\% of total samples were infected with Babesia odocoilei [62]. (Table 2). Recently, B. odocoilei was identified in two human subjects and was shown to be pathogenic to humans [63]. However, out of these two confirmed cases, one confirmed I. scapularis bite, and another patient could not recall a tick bite; therefore, tick species are unknown [63]. It was also revealed that $B$. odocoile $i$ serologically cross-reacts with Babesia duncani, an emerging tickborne pathogen (TBP) in Canada and has also been known to be widespread in the continental USA [64]. Although there is substantive evidence that ixodid ticks on the west coast (i.e., Ixodes angustus, Ixodes pacificus, and Ixodes spinipalpis) are vectors of $B$. duncani, this has not been yet experimentally confirmed [65]. Depending on the species of Babesia, this zoonotic parasite can be transmitted in ticks by transovarial transmission (female to eggs to larvae) and, also, via transstadial transmission (larvae to nymphs to adults). It is important for the clinicians to realize that there are more than two Babesia spp. in North America that causes human babesiosis. Many TBPs have been identified in recent decades, and continuing research is needed in this area. 


\subsection{Bartonella Species}

Bartonella is a genus of bacteria present in many arthropod vectors [66] and infects I. pacificus ticks in California. In Santa Clara County, CA, 19.2\% of 151 individually tested ticks were positive for Bartonella. Additionally, male ticks were more likely to be infected with Bartonella than female ticks [66]. Molecular analysis showed a variety of Bartonella strains, which were closely related to cattle Bartonella and several known humanpathogenic Bartonella species and subspecies: B. henselae, B. quintana, B. washoensis, and B. vinsonii subsp. berkhoffii, suggesting that I. pacificus adults could be a source for Bartonella infections in humans [66]. In another study, adult I. pacificus were collected from six California counties: El Dorado, Los Angeles, Orange, Santa Cruz, Shasta, and Sonoma. Except for Los Angeles County, ticks from all other counties tested positive for Bartonella [67]. Another study conducted in two northern California counties (Sonoma and Yolo) isolated Bartonella from ground squirrels (Otospermophilus beecheyi) and various other rodent species (Peromyscus maniculatus, P. boylii, P. truei and Neotoma fuscipes). Overall, Bartonella spp. were isolated from the blood of $71 \%(32 / 45)$ of the ground squirrels and $1 / 3(22 / 66)$ of the other rodents [68] (Table 2). Ground squirrel isolates were most closely related to B. washoensis, whereas the other rodent isolates were closest to $B$. vinsonii subsp. vinsonii and $B$. vinsonii subsp. arupensis. The overall prevalence of Bartonella in rodents from Sonoma (33.3\%) was comparable with reports from other regions of North America [69-71]. Two species isolated in northern California (B. vinsonii subsp. arupensis and B. washoensis) have been described as zoonotic pathogens [72-74].

\subsection{Borrelia Species}

Ixodes pacificus is the vector of Borrelia burgdorferi, the causative agent of Lyme disease, the most important tickborne disease in the United States. From 2003 to 2007, I. pacificus nymphs were collected from Mendocino, CA, and DNA was extracted for B. burgdorferi detection [75]. In total, 47 of the 322 (14.6\%) I. pacificus ticks were positive for B. burgdorferi. Interestingly, the infection prevalence of B. burgdorferi was higher in I. pacificus nymphs collected from tree trunks instead of logs but higher in logs than leaf litter or grass [75]. In another study, $9.5 \%$ of I. pacificus nymphs and $1.4 \%$ of adults collected in southern California were positive for B. burgdorferi [76]. Nymphs tend to have a higher prevalence of B. burgdorferi than adult ticks from the same generational cohort [76].

Tick hosts maintain Borrelia in the environment, especially small mammals and birds. The order Passeriformes, and more specifically the family Emberizidae, may play a critical role in distributing and maintaining I. pacificus and B. burgdorferi in California [45]. The western grey squirrel (Sciurus griseus) is thought to be an important host in maintaining B. burgdorferi s.s. in woodland habitats [77]. Conversely, many lizard species which are commonly parasitized by immature I. pacificus, have a serum that is highly lytic to Borrelia species, allowing them to eliminate the pathogen and therefore not play a role in maintaining this bacterium in the population [78] (Table 2).

In Napa County in 2008, two out of the $150(1.3 \%)$ adult ticks were infected with B. burgdorferi. In 2009, only one of the 130 adult ticks collected tested positive for B. burgdorferi [46]. Wright and colleagues (2011) tested I. pacificus larvae fed on rodents; 2 out of 215 larvae were positive; however, none were positive in a different cohort. Instead, in this cohort, 3 of 204 I. pacificus larvae feeding on bird species tested positive for B. burgdorferi [46]. In a recent study from Salkeld et al., 2.9-3.7\% I. pacificus adults were infected with B. burgdorferi, but multiple sites exhibited a much higher prevalence than expected by the confidence intervals (2.3-3.7\%). In contrast, nymphal ticks had an infection rate of $3.2-6.2 \%$ [79]. Prevalence varied from site to site, and some sites had a much higher prevalence than the average [79].

Out of 288 adults and 67 nymphs, none were positive for B. burgdorferi in Southern California [41]. A more recent, broader study was conducted in California, Oregon, and Washington to record pathogen prevalence in Ixodes tick species. Out of 381 I. pacificus tick samples (adults and nymphs), 302 were from California, and $1.32 \%$ were infected 
with B. burgdorferi; 48 were collected in Oregon, and $2.08 \%$ of them were infected; and in Washington out of $31 \mathrm{I}$. pacificus, none were positive [21]. In all three states mentioned above, B. burgdorferi prevalence in I. pacificus nymphs was higher than in adults [21].

Genetic diversity of $B$. burgdorferi in different tick populations and their host community has been observed. In Marin and Sonoma counties, 31 unique B. burgdorferi haplotypes were found [80]. Some haplotypes were unique to specific sites, suggesting that genetic drift occurs between multiple separate populations [80]. Furthermore, the frequency of the most common haplotypes (1, 2, and 3) varied depending on the site and year. Mammals sampled from these areas carried the most common haplotypes; however, higher B. burgdorferi s.s. diversity in mammals was observed than the ticks.

In addition to B. burgdorferi, other species of Borrelia are known to be carried by I. pacificus; one of those being B. miyamotoi. In a study conducted by Salkeld et al., the prevalence of $B$. miyamotoi in adult ticks in coastal central and northern California counties was $1.3 \%$ and as high as $3.9 \%$ in some areas. In nymphs, the regional B. miyamotoi prevalence was $5.1 \%$, with specific locations such as Bolinas Lagoon in Marin County had a much higher prevalence of $17.8 \%$ [79]. Other less known species have been reported in I. pacificus populations, such as B. americana and B. bissettiae. B. americana was identified in three adults $I$. pacificus while B. bissettiae was observed just once [79] (Table 2). These data were aggregated, suggesting the possibility of underrepresenting the actual distribution of pathogens in these populations. In Mendocino County, Mun et al. found 0.7-1.7\% prevalence of B. miyamotoi s.l. in host-seeking I. pacificus [81].

Borrelia miyamotoi is considered an emerging causative agent for relapsing fever, and its ability to be transmitted vertically, horizontally, and transstadially may allow it to spread more efficiently [82]. Nymphal infection with B. miyamotoi was 45-fold higher than the larvae, while the adult prevalence was 1.8-fold greater than nymphs [82]. Horizontal transmission accounted for $>97 \%$ of nymphal infections and $43 \%$ of adult infections [82].

Although this review has been primarily focused on I. pacificus, it is worth noting that I. spinipalpis, a non-human biting tick, may also play a role as a vector of Borrelia spp. In a recent citizen science study, Ixodes ticks were submitted from California, Oregon, and Washington. The infection prevalence of B. burgdorferi s. l. and B. miyamotoi in I. pacificus ticks was $1.31 \%$ and $1.05 \%$, respectively, and the prevalence of $B$. burgdorferi s. $l$. in I. spinipalpis ticks was $14.29 \%$. Furthermore, two species within the B. burgdorferi s. $l$. complex were detected in West Coast ticks: B. burgdorferi s.s. and B. lanei. Ixodes spinipalpis had the highest prevalence of $B$. lanei which may indicate a possible public health threat, and the enzootic life cycle and pathogenicity of B. lanei warrant further study [21].

\subsection{Rickettsiales Bacteria}

\subsubsection{Rickettsia Species}

Rickettsiaceae is a family of bacteria most commonly transmitted by an arthropod vector, especially ticks. Pathogenic Rickettsia species associated with I. pacificus have not been recorded yet. However, an endosymbiont rickettsial phylotype, Rickettsia monacensis strain Humboldt (formerly known as Rickettsia species phylotype G021), and a novel phylotype G022, which is related to a distant spotted fever group, have been identified in I. pacificus [83].

Both vertical and transstadial transmission routes of Rickettsia pathogens in I. pacificus have been confirmed. All I. pacificus ticks tested were positive for the phylotype G021 (100\% prevalence), a critical component of I. pacificus' microbiome [83]. However, another study suggested that the burden of phylotype G021 significantly differed between collection sites and habitats. The phylotype G021 burden was lower in ticks collected in southern California compared to central and northern California [84]. Rickettsia burden also varies by developmental stage; engorged ticks of all life stages have a significantly higher burden of rickettsial phylotype G021 than unfed. However, Rickettsia burden was lower in larval ticks than in adults [85]. Rickettsia species phylotype G021 can synthesize folate de novo, suggesting that it might benefit the tick $[86,87]$. However, antibiotic treatment in 
I. pacificus did not affect embryogenesis, oviposition, or egg hatching [88]. While Rickettsia endosymbionts may provide nutritional support for I. pacificus ticks, they are assumed to be facultative and not required for the development [88].

Prevalence of the novel phenotype G022 in Napa valley, CA, was 2.0\% compared to $100 \%$ of G021 in the same counties. No significant correlation was found between the burden of the phylotype G021 in the presence and absence of the phylotype G022, suggesting that the presence of these Rickettsia species do not interfere with each other [84].

\subsubsection{Anaplasma Species}

Anaplasma phagocytophilum is a rickettsial parasite of humans and other animals and is the causative agent of human granulocytic anaplasmosis. Originally, A. phagocytophilum was classified as Ehrlichia equi and E. phagocytophila [89] but $A$. phagocytophilum was reclassified in 2001. Studies suggest that there might be multiple strains of $A$. phagocytophilum present in the environment [90]. In the western USA, I. pacificus is a competent vector of A. phagocytophilum [91,92]. A total of 2100 rodents, 20 shrews, and one lagomorph, were evaluated for exposure to and infection with A. phagocytophilum and infestation with Ixodes ticks [93]. The overall seroprevalence was $15.2 \%$, and the highest values were recorded in dusky-footed woodrats, tree squirrels, and chipmunk species [93]. Anaplasma phagocytophilum was also detected in lizards and snakes in California. However, experimental inoculation and feeding by ticks on the infected hosts suggested that they do not serve as primary reservoir hosts of this Rickettsia [94]. In 2011 and 2012, blood samples and ticks were collected from 349 individual birds from 48 species in Napa and Yolo counties in California to detect $A$. phagocytophilum and B. burgdorferi using pathogen-specific PCR. A higher percentage of ticks in Napa County were infected with A. phagocytophilum than at the Yolo County site. Blood samples from a golden-crowned sparrow (Zonotrichia atricapilla) and a European starling (Sturnus vulgaris) were positive for A. phagocytophilum DNA at very low levels [95]. In nymphal and adult I. pacificus, A. phagocytophilum prevalence was $1 \%$ and $10 \%$, respectively [95]. The reservoir hosts on which I. pacificus feed have implications in the genetic diversity of A. phagocytophilum [90]. Most strains detected were genetically distinct and consistent with those found in reservoir hosts, humans, dogs, and horses [90]. Ixodes pacificus feeds on larger mammals and many migratory birds that can travel long distances (Table 2) and could lead to rapid, widespread dispersion of A. phagocytophilum that may increase human granulocytic anaplasmosis cases.

\subsubsection{Ehrlichia Species}

Pathogens from the genus Ehrlichia are the causative agents of two main human infections, human monocytic ehrlichiosis and human granulocytic ehrlichiosis (HGE). Ixodes pacificus ticks can carry both pathogens, E. chaffeensis and the unnamed species which cause HGE. As mentioned above, I. pacificus also carries the strain E. equi, the causative agent of equine granulocytic ehrlichiosis (EGE) [96]. Individual I. pacificus carrying HGE and the horse pathogen E. equi has been reported in northern California [96]. In California, an infection rate of $3.4 \%$ and $2.0 \%$ for E. chaffeensis and the causative agent of HGE, respectively, was noted in I. pacificus [97]. Naturally infected I. pacificus has been shown to transmit E. equi to previously uninfected horses experimentally; however, natural infection in the field has not been seen [97,98]. In addition to the above species, Rickettsia of the E. phagocytophila genogroup is known to be carried by Ixodid ticks. It has been found to infect equines, ruminants, dogs, and humans (Table 2). One study found this pathogen to infect llamas and was transmitted by I. pacificus ticks [99]. 
Table 2. Pathogens and reservoir hosts associated with Ixodes pacificus. These data are adapted from several publications as indicated in the reference column.

\begin{tabular}{|c|c|c|c|}
\hline Disease & Pathogen & Reservoir Host & Reference \\
\hline Babesiosis & Babesia odocoilei & Deer species & [61-65] \\
\hline Bartonellosis & $\begin{array}{c}\text { Bartonella hensele, } \text { B. quintana, } \\
\text { B. washoensis, B. vinsonii } \\
\text { subsp. berkhoffi }\end{array}$ & $\begin{array}{c}\text { Ground squirrel } \\
\text { (Otospermophilus beecheyi), Deer } \\
\text { mouse (Peromyscus maniculatus), } \\
\text { Brush mouse (P.boylii), Pinyon } \\
\text { mouse (P. truei), Dusky-footed } \\
\text { woodrat (Neotoma fuscipes) }\end{array}$ & [66-74] \\
\hline $\begin{array}{l}\text { Lyme Disease (B. burgdorferi), } \\
\text { Hard Tick Relapsing Fever } \\
\text { (B. miyamotoi) }\end{array}$ & $\begin{array}{l}\text { Borrelia burgdorferi, } B . \\
\text { miyamotoi, B. americana, } \\
\text { B. bissettiae }\end{array}$ & $\begin{array}{c}\text { Western grey squirrel } \\
\text { (Sciurus griseus), birds of the order } \\
\text { Passeriforms }\end{array}$ & {$[21,41,45,46,75-82]$} \\
\hline Anaplasmosis & Anaplasma phagocytophilum & $\begin{array}{c}\text { Dusky-footed woodrat } \\
\text { (Neotoma fuscipes), Tree squirrels } \\
\text { (Sciurus sp.), Chipmunk } \\
\text { (Tamias sp.), Golden-crowned } \\
\text { sparrow (Zonotrichia atricapilla), } \\
\text { European starling } \\
\text { (Sturnus vulgaris) }\end{array}$ & [89-94] \\
\hline $\begin{array}{c}\text { Human Monocytic } \\
\text { Ehrlichosis, Human } \\
\text { Granulocytic Ehrlichosis }\end{array}$ & $\begin{array}{c}\text { Ehrlichia chaffensis, E. equi, } \\
\text { E. phagocytophila }\end{array}$ & Deer species & [96-99] \\
\hline
\end{tabular}

\section{Pathogen Coinfection in I. pacificus}

Coinfection with pathogens has been recorded in both ticks and their hosts. In a study performed in Northern California, authors tested western grey squirrels (Scirus griseus), eastern grey squirrels (S. carolinensis), an eastern fox squirrel (S. niger), Douglas squirrels (Tamiasciurus douglasii), and northern flying squirrels (Glaucomys sabrinus) for evidence of coinfection. A total of $14 \%$ of grey squirrels were infected with B. burgdorferi and A. phagocytophilum [100]. Coinfection has also been recorded in deer mice, specifically P. maniculatus, one of the main hosts for I. pacificus [101]. In another study, approximately $1 \%$ of I. pacificus were coinfected with B. burgdorferi and A. phagocytophilum, and $0.12 \%$ were coinfected with B. burgdorferi and E. chaffeensis [102]. However, no I. pacificus was coinfected with E. chaffeensis and A. phagocytophilum, suggesting that only specific coinfections may be able to occur naturally [102]. In a study conducted in Washington state, I. pacificus ticks were coinfected with B. burgdorferi s.s. and B. miyamotoi, as well as Borrelia spp. and A. phagocytophilum [103]. Future studies of pathogen prevalence in I. pacificus populations should identify coinfections and understand interactions between different pathogens and their hosts.

\section{Tick Control}

Tick control is crucial in curbing the impact of tickborne diseases (TBDs). While chemical acaricides such as pyrethroids and organophosphates are mainstay of tick control, the potential of botanical acaricides as an adequate repellant has also been assessed [104]. However, resistance is an increasingly pressing issue and additional integrated tick control measures such as landscape management [105], vaccines targeted for humans [106], deer and rodent targeted vaccines $[105,107]$, and personal protection measures (PPM) need to be taken to adequately control tick populations.

Practicing PPM such as staying on trails, applying insect repellent (on skin and clothing), conducting a body check after being outdoors, washing clothes in hot water, and wearing clothing with good coverage (including tucking pants into socks) is essential [108]. For example, in several studies in the Midwest and the northeastern USA, researchers found that people who used insect repellent and performed a thorough body check after being 
outdoors were less likely to report a TBD diagnosis [108-110], suggesting the importance of PPM.

\section{Conclusions}

Expanding tick habitats and consistent identification of new TBP require long-term studies on tick ecology and TBPs epidemiology. Most of our information on the tick-hostpathogen system comes from very few species, namely I. scapularis and I. ricinus. Therefore, it leads to a bias and does not reflect the complex dynamics of other Ixodes ticks and their associated hosts and pathogens. The pacific west region contains various habitat types at varying degrees of suitability for I. pacificus and other Ixodes species and many vertebrate host species. Most work has been carried out in California due to better vector surveillance and higher incidence of Lyme disease and other TBD cases than in other western states. Tick-borne diseases involve a complex dynamic system of vectors, hosts, and abiotic and biotic factors. To fully understand these systems, interdisciplinary teams with expertise in tick biology, tick genetics and genomics, computational biology, geography, meteorology, veterinary and human health, as well as vector-control districts and public health, need to work together. This review highlights the gaps in knowledge and the research required to have a more comprehensive picture of tick species and TBD dynamics on the west coast.

Author Contributions: M.G.-N. and I.R. conceptualized and designed the work. I.R. and M.M. acquired, analyzed and interpreted data. M.G.-N., M.M. and I.R. drafted and revised the work. M.G.-N. supervised and obtained funding. J.B.R. analyzed and interpreted some data and constructed figures. M.G.-N., M.M. and I.R. wrote the final draft. All authors have read and agreed to the published version of the manuscript.

Funding: This research was funded by National Science Foundation grant number 2019609 and the Pacific Southwest Center of Excellence in Vector-Borne diseases (AWD27170) to M.G.-N.

Institutional Review Board Statement: Not applicable.

Informed Consent Statement: Not applicable.

Data Availability Statement: Not applicable.

Acknowledgments: We thank Andrew Nuss for his insight during the course of writing this manuscript. We also thank anonymous reviewers who helped improve the manuscript.

Conflicts of Interest: The authors declare no conflict of interest. The sponsors had no role in the study's design, execution, interpretation, or writing.

\section{References}

1. Caminade, C.; McIntyre, K.M.; Jones, A.E. Impact of recent and future climate change on vector-borne diseases. Ann. N. Y. Acad. Sci. 2019, 1436, 157-173. [CrossRef]

2. Kilpatrick, A.M.; Randolph, S.E. Drivers, dynamics, and control of emerging vector-borne zoonotic diseases. Lancet 2012, 380, 1946-1955. [CrossRef]

3. Ogden, N.H.; Artsob, H.; Lindsay, L.R.; Sockett, P.N. Lyme disease: A zoonotic disease of increasing importance to Canadians. Can. Fam. Physician 2008, 54, 1381-1384.

4. Pascoe, E.L.; Plourde, B.T.; Lopéz-Perez, A.M.; Foley, J.E. Response of small mammal and tick communities to a catastrophic wildfire and implications for tickborne pathogens. J. Vector Ecol. 2020, 45, 269-284. [CrossRef]

5. Allan, B.F. Influence of prescribed burns on the abundance of Amblyomma americanum (Acari: Ixodidae) in the Missouri Ozarks. J. Med. Entomol. 2009, 46, 1030-1036. [CrossRef]

6. Estrada-Peña, A.; Ostfeld, R.S.; Peterson, A.T.; Poulin, R.; de la Fuente, J. Effects of environmental change on zoonotic disease risk: An ecological primer. Trends Parasitol. 2014, 30, 205-214. [CrossRef]

7. Diuk-Wasser, M.A.; Hoen, A.G.; Cislo, P.; Brinkerhoff, R.; Hamer, S.A.; Rowland, M.; Cortinas, R.; Vourc'h, G.; Melton, F.; Hickling, G.J.; et al. Human risk of infection with Borrelia burgdorferi, the Lyme disease agent, in eastern United States. Am. J. Trop. Med. Hyg. 2012, 86, 320-327. [CrossRef]

8. Piesman, J.; Eisen, L. Prevention of tickborne diseases. Annu. Rev. Entomol. 2008, 53, 323-343. [CrossRef] [PubMed]

9. Burgdorfer, W.; Lane, R.S.; Barbour, A.G.; Gresbrink, R.A.; Anderson, J.R. The western black-legged tick, Ixodes pacificus: A vector of Borrelia burgdorferi. Am. J. Trop. Med. Hyg. 1985, 34, 925-930. [CrossRef] [PubMed] 
10. Lane, R.S.; Brown, R.N.; Piesman, J.; Peavey, C.A. Vector competence of Ixodes pacificus and Dermacentor occidentalis (Acari: Ixodidae) for various isolates of Lyme disease spirochetes. J. Med. Entomol. 1994, 31, 417-424. [CrossRef] [PubMed]

11. Eisen, R.J.; Eisen, L.; Beard, C.B. County-Scale Distribution of Ixodes scapularis and Ixodes pacificus (Acari: Ixodidae) in the Continental United States. J. Med. Entomol. 2016, 53, 349-386. [CrossRef] [PubMed]

12. Clover, J.R.; Lane, R.S. Evidence implicating nymphal Ixodes pacificus (Acari: Ixodidae) in the epidemiology of Lyme disease in California. Am. J. Trop. Med. Hyg. 1995, 53, 237-240. [CrossRef] [PubMed]

13. Rollend, L.; Fish, D.; Childs, J.E. Transovarial transmission of Borrelia spirochetes by Ixodes scapularis: A summary of the literature and recent observations. Ticks Tick Borne Dis. 2013, 4, 46-51. [CrossRef]

14. Kurokawa, C.; Lynn, G.E.; Pedra, J.; Pal, U.; Narasimhan, S.; Fikrig, E. Interactions between Borrelia burgdorferi and ticks. Nat. Rev. Microbiol. 2020, 18, 587-600. [CrossRef] [PubMed]

15. Kurtenbach, K.; Hanincová, K.; Tsao, J.I.; Margos, G.; Fish, D.; Ogden, N.H. Fundamental processes in the evolutionary ecology of Lyme borreliosis. Nat. Rev. Microbiol. 2006, 4, 660-669. [CrossRef] [PubMed]

16. Hauck, D.; Jordan, D.; Springer, A.; Schunack, B.; Pachnicke, S.; Fingerle, V.; Strube, C. Transovarial transmission of Borrelia spp., Rickettsia spp. and Anaplasma phagocytophilum in Ixodes ricinus under field conditions extrapolated from DNA detection in questing larvae. Parasit. Vectors 2020, 13, 176. [CrossRef]

17. Centers for Disease Control and Prevention. How Ticks Spread Disease. Available online: https://www.cdc.gov/ticks/life_ cycle_and_hosts.html (accessed on 21 November 2021).

18. Girard, Y.A.; Travinsky, B.; Schotthoefer, A.; Fedorova, N.; Eisen, R.J.; Eisen, L.; Barbour, A.G.; Lane, R.S. Population structure of the Lyme borreliosis spirochete Borrelia burgdorferi in the western black-legged tick (Ixodes pacificus) in Northern California. Appl. Environ. Microbiol. 2009, 75, 7243-7252. [CrossRef]

19. Merten, H.A.; Durden, L.A. A state-by-state survey of ticks recorded from humans in the United States. J. Vector Ecol. 2000, 25, 102-113.

20. Brown, R.N.; Lane, R.S. Lyme disease in California: A novel enzootic transmission cycle of Borrelia burgdorferi. Science 1992, 256, 1439-1442. [CrossRef]

21. Xu, G.; Pearson, P.; Dykstra, E.; Andrews, E.S.; Rich, S.M. Human-Biting Ixodes Ticks and Pathogen Prevalence from California, Oregon, and Washington. Vector Borne Zoonotic Dis. 2019, 19, 106-114. [CrossRef]

22. Margos, G.; Hojgaard, A.; Lane, R.S.; Cornet, M.; Fingerle, V.; Rudenko, N.; Ogden, N.; Aanensen, D.M.; Fish, D.; Piesman, J Multilocus sequence analysis of Borrelia bissettii strains from North America reveals a new Borrelia species, Borrelia kurtenbachii. Ticks Tick Borne Dis. 2010, 1, 151-158. [CrossRef] [PubMed]

23. Margos, G.; Piesman, J.; Lane, R.S.; Ogden, N.H.; Sing, A.; Straubinger, R.K.; Fingerle, V. Borrelia kurtenbachii sp. nov., a widely distributed member of the Borrelia burgdorferi sensu lato species complex in North America. Int. J. Syst. 2014, 64 Pt 1, 128-130. [CrossRef] [PubMed]

24. Rudenko, N.; Golovchenko, M.; Lin, T.; Gao, L.; Grubhoffer, L.; Oliver, J.H., Jr. Delineation of a new species of the Borrelia burgdorferi Sensu Lato Complex, Borrelia americana sp. nov. J. Clin. Microbiol. 2009, 47, 3875-3880. [CrossRef] [PubMed]

25. Postic, D.; Ras, N.M.; Lane, R.S.; Hendson, M.; Baranton, G. Expanded diversity among Californian Borrelia isolates and description of Borrelia bissettii sp. nov. (formerly Borrelia group DN127). J. Clin. Microbiol. 1998, 36, 3497-3504. [CrossRef] [PubMed]

26. Postic, D.; Garnier, M.; Baranton, G. Multilocus sequence analysis of atypical Borrelia burgdorferi sensu lato isolates-Description of Borrelia californiensis sp. nov., and genomospecies 1 and 2. Int. J. Med. Microbiol. 2007, 297, 263-271. [CrossRef]

27. Margos, G.; Fedorova, N.; Kleinjan, J.E.; Hartberger, C.; Schwan, T.G.; Sing, A.; Fingerle, V. Borrelia lanei sp. nov. extends the diversity of Borrelia species in California. Int. J. Syst. 2017, 67, 3872-3876. [CrossRef]

28. Schwartz, A.M.; Hinckley, A.F.; Mead, P.S.; Hook, S.A.; Kugeler, K.J. Surveillance for Lyme Disease-United States, $2008-2015$. Morb. Mortal. Wkly. Report. Surveill. Summ. 2017, 66, 1-12. [CrossRef]

29. Spielman, A.; Wilson, M.L.; Levine, J.F.; Piesman, J. Ecology of Ixodes dammini-borne human babesiosis and Lyme disease. Ann. Rev. Entomol. 1985, 30, 439-460. [CrossRef]

30. Salkeld, D.J.; Leonhard, S.; Girard, Y.A.; Hahn, N.; Mun, J.; Padgett, K.A.; Lane, R.S. Identifying the reservoir hosts of the Lyme disease spirochete Borrelia burgdorferi in California: The role of the western gray squirrel (Sciurus griseus). Am. J. Trop. Med. Hyg. 2008, 79, 535-540. [CrossRef]

31. Salkeld, D.J.; Castro, M.B.; Bonilla, D.; Kjemtrup, A.; Kramer, V.L.; Lane, R.S.; Padgett, K.A. Seasonal activity patterns of the western black-legged tick, Ixodes pacificus, in relation to onset of human Lyme disease in northwestern California. Ticks Tick Borne Dis. 2014, 5, 790-796. [CrossRef]

32. Salkeld, D.J.; Lane, R.S. Community ecology and disease risk: Lizards, squirrels, and the Lyme disease spirochete in California, USA. Ecology 2010, 91, 293-298. [CrossRef] [PubMed]

33. Hahn, M.B.; Jarnevich, C.S.; Monaghan, A.J.; Eisen, R.J. Modeling the Geographic Distribution of Ixodes scapularis and Ixodes pacificus (Acari: Ixodidae) in the Contiguous United States. J. Med. Entomol. 2016, 53, 1176-1191. [CrossRef] [PubMed]

34. Eisen, L.; Eisen, R.J.; Lane, R.S. Geographical distribution patterns and habitat suitability models for presence of host-seeking ixodid ticks in dense woodlands of Mendocino County, California. J. Med. Entomol. 2006, 43, 415-427. [CrossRef]

35. Lane, R.S.; Manweiler, S.A.; Stubbs, H.A.; Lennette, E.T.; Madigan, J.E.; Lavoie, P.E. Risk factors for Lyme disease in a small rural community in northern California. Am. J. Epidemiol. 1992, 136, 1358-1368. [CrossRef] [PubMed] 
36. Padgett, K.; Bonilla, D.; Kjemtrup, A.; Vilcins, I.M.; Yoshimizu, M.H.; Hui, L.; Sola, M.; Quintana, M.; Kramer, V. Large scale spatial risk and comparative prevalence of Borrelia miyamotoi and Borrelia burgdorferi sensu lato in Ixodes pacificus. PLoS ONE 2014, 9, e110853. [CrossRef]

37. Billeter, S.A.; Yoshimizu, M.H.; Hu, R. Species composition and temporal distribution of adult ixodid ticks and prevalence of Borrelia burgdorferi sensu lato and Rickettsia species in Orange County, California. J. Vector Ecol. 2017, 42, 189-192. [CrossRef] [PubMed]

38. Dennis, D.T.; Nekomoto, T.S.; Victor, J.C.; Paul, W.S.; Piesman, J. Reported distribution of Ixodes scapularis and Ixodes pacificus (Acari: Ixodidae) in the United States. J. Med. Entomol. 1998, 35, 629-638. [CrossRef]

39. MacDonald, A.J.; Briggs, C.J. Truncated seasonal activity patterns of the western blacklegged tick (Ixodes pacificus) in central and southern California. Ticks Tick Borne Dis. Dis. 2016, 7, 234-242. [CrossRef]

40. Slowik, T.J.; Lane, R.S. Nymphs of the western black-legged tick (Ixodes pacificus) collected from tree trunks in woodland-grass habitat. J. Vector Ecol. 2001, 26, 165-171.

41. Macdonald, A.J.; Hyon, D.W.; Brewington, J.B.; O'Connor, K.E.; Swei, A.; Briggs, C.J. Lyme disease risk in southern California: Abiotic and environmental drivers of Ixodes pacificus (Acari: Ixodidae) density and infection prevalence with Borrelia burgdorferi. Parasit. Vectors 2017, 10, 7. [CrossRef]

42. Padgett, K.A.; Bonilla, D.L. Novel exposure sites for nymphal Ixodes pacificus within picnic areas. Ticks Tick Borne Dis. 2011, 2, 191-195. [CrossRef]

43. Davis, R.S.; Ramirez, R.A.; Anderson, J.L.; Bernhardt, S.A. Distribution and Habitat of Ixodes pacificus (Acari: Ixodidae) and Prevalence of Borrelia burgdorferi in Utah. J. Med. Entomol. 2015, 52, 1361-1367. [CrossRef]

44. Porter, W.T.; Barrand, Z.A.; Wachara, J.; Davall, K.; Mihaljevic, J.R.; Pearson, T.; Salkeld, D.J.; Nieto, N.C. Predicting the current and future distribution of the western black-legged tick, Ixodes pacificus, across the Western US using citizen science collections. PLOS ONE 2021, 16, e0244754. [CrossRef] [PubMed]

45. Castro, M.B.; Wright, S.A. Vertebrate hosts of Ixodes pacificus (Acari: Ixodidae) in California. J. Vector Ecol. 2007, 32, 140-149. [CrossRef]

46. Wright, S.A.; Tucker, J.R.; Donohue, A.M.; Castro, M.B.; Kelley, K.L.; Novak, M.G.; Macedo, P.A. Avian Hosts of Ixodes pacificus (Acari: Ixodidae) and the Detection of Borrelia burgdorferi in Larvae Feeding on the Oregon Junco. J. Med. Entomol. 2011, 48, 852-859. [CrossRef] [PubMed]

47. Nieto, N.C.; Holmes, E.A.; Foley, J.E. Survival rates of immature Ixodes pacificus (Acari: Ixodidae) ticks estimated using field-placed enclosures. J. Vector Ecol. 2010, 35, 43-49. [CrossRef] [PubMed]

48. Eisen, L.; Eisen, R.J.; Lane, R.S. The roles of birds, lizards, and rodents as hosts for the western black-legged tick Ixodes pacificus. J. Vector Ecol. 2004, 29, 295-308.

49. Eisen, L.; Eisen, R.J.; Lane, R.S. Seasonal activity patterns of Ixodes pacificus nymphs in relation to climatic conditions. Med. Vet. Entomol. 2002, 16, 235-244. [CrossRef]

50. Macdonald, A.J.; O’Neill, C.; Yoshimizu, M.H.; Padgett, K.A.; Larsen, A.E. Tracking seasonal activity of the western blacklegged tick across California. J. Appl. Ecol. 2019, 56, 2562-2573. [CrossRef]

51. Peavey, C.A.; Lane, R.S. Field and laboratory studies on the timing of oviposition and hatching of the western black-legged tick, Ixodes pacificus (Acari: Ixodidae). Exp. Appl. Acarol. 1996, 20, 695-711. [CrossRef]

52. Padgett, K.A.; Lane, R.S. Life cycle of Ixodes pacificus (Acari: Ixodidae): Timing of developmental processes under field and laboratory conditions. J. Med. Entomol. 2001, 38, 684-693. [CrossRef]

53. Swei, A.; Meentemeyer, R.; Briggs, C.J. Influence of Abiotic and Environmental Factors on the Density and Infection Prevalence of Ixodes pacificus (Acari: Ixodidae) With Borrelia burgdorferi. J. Med. Entomol. 2011, 48, 20-28. [CrossRef]

54. Eisen, R.J.; Eisen, L.; Ogden, N.H.; Beard, C.B. Linkages of Weather and Climate with Ixodes scapularis and Ixodes pacificus (Acari: Ixodidae), Enzootic Transmission of Borrelia burgdorferi, and Lyme Disease in North America. J. Med. Entomol. 2016, 53, $250-261$. [CrossRef]

55. Eisen, R.J.; Feirer, S.; Padgett, K.A.; Hahn, M.B.; Monaghan, A.J.; Kramer, V.L.; Lane, R.S.; Kelly, M. Modeling Climate Suitability of the Western Blacklegged Tick in California. J. Med. Entomol. 2018, 55, 1133-1142. [CrossRef]

56. Macdonald, A.J.; Mccomb, S.; O'Neill, C.; Padgett, K.A.; Larsen, A.E. Projected climate and land use change alter western blacklegged tick phenology, seasonal host-seeking suitability and human encounter risk in California. Glob. Chang. Biol. 2020, 26, 5459-5474. [CrossRef]

57. Macdonald, A.J.; Hyon, D.W.; Mcdaniels, A.; O'Connor, K.E.; Swei, A.; Briggs, C.J. Risk of vector tick exposure initially increases, then declines through time in response to wildfire in California. Ecosphere 2018, 9, e02227. [CrossRef]

58. Padgett, K.A.; Casher, L.E.; Stephens, S.L.; Lane, R.S. Effect of Prescribed Fire for Tick Control in California Chaparral. J. Med. Entomol. 2009, 46, 1138-1145. [CrossRef]

59. Macdonald, A.J. Abiotic and habitat drivers of tick vector abundance, diversity, phenology and human encounter risk in southern California. PLoS ONE 2018, 13, e0201665. [CrossRef]

60. Eisen, R.J.; Clark, R.J.; Monaghan, A.J.; Eisen, L.; Delorey, M.J.; Beard, C.B. Host-Seeking Phenology of Ixodes pacificus (Acari: Ixodidae) Nymphs in Northwestern California in Relation to Calendar Week, Woodland Type, and Weather Conditions. J. Med. Entomol. 2017, 54, 125-131. [CrossRef] 
61. Westblade, L.F.; Simon, M.S.; Mathison, B.A.; Kirkman, L.A. Babesia microti: From Mice to Ticks to an Increasing Number of Highly Susceptible Humans. J. Clin. Microbiol. 2017, 55, 2903-2912. [CrossRef]

62. Eshoo, M.W.; Carolan, H.E.; Massire, C.; Chou, D.M.; Crowder, C.D.; Rounds, M.A.; Phillipson, C.A.; Schutzer, S.E.; Ecker, D.J. Survey of Ixodes pacificus Ticks in California Reveals a Diversity of Microorganisms and a Novel and Widespread Anaplasmataceae Species. PLoS ONE 2015, 10, e0135828. [CrossRef] [PubMed]

63. Scott, J.D.; Sajid, M.S.; Pascoe, E.L.; Foley, J.E. Detection of Babesia odocoilei in Humans with Babesiosis Symptoms. Diagnostics 2021, 11, 947. [CrossRef] [PubMed]

64. Scott, J.D.; Scott, C.M. Human Babesiosis Caused by Babesia duncani Has Widespread Distribution across Canada. Healthcare 2018, 6, 49. [CrossRef]

65. Liu, D.; Lu, X. Molecular Detection of Human Parasitic Pathogens, 1st ed.; Liu, D., Ed.; CRC Press: Boca Raton, FL, USA, 2012. [CrossRef]

66. Chang, C.C.; Chomel, B.B.; Kasten, R.W.; Romano, V.; Tietze, N. Molecular Evidence of Bartonella spp. in Questing Adult Ixodes pacificus Ticks in California. J. Clin. Microbiol. 2001, 39, 1221-1226. [CrossRef]

67. Chang, C.C.; Hayashidani, H.; Pusterla, N.; Kasten, R.W.; Madigan, J.E.; Chomel, B.B. Investigation of Bartonella infection in ixodid ticks from California. Comp. Immunol. Microbiol. Infect. Dis. 2002, 25, 229-236. [CrossRef]

68. Ziedins, A.C.; Chomel, B.B.; Kasten, R.W.; Kjemtrup, A.M.; Chang, C.-C. Molecular epidemiology of Bartonella species isolated from ground squirrels and other rodents in northern California. Epidemiol. Infect. 2016, 144, 1837-1844. [CrossRef]

69. Kosoy, M.Y.; Regnery, R.L.; Tzianabos, T.; Marston, E.L.; Jones, D.C.; Green, D.; Maupin, G.O.; Olson, J.G.; Childs, J.E. Distribution, diversity, and host specificity of Bartonella in rodents from the Southeastern United States. Am. J. Trop. Med. Hyg. 1997, 57, 578-588. [CrossRef]

70. Jardine, C.; Appleyard, G.; Kosoy, M.Y.; McColl, D.; Chirino-Trejo, M.; Wobeser, G.; Leighton, F.A. Rodent-associated Bartonella in Saskatchewan, Canada. Vector-Borne Zoonotic Dis. 2005, 5, 402-409. [CrossRef]

71. Bai, Y.; Kosoy, M.Y.; Ray, C.; Brinkerhoff, R.J.; Collinge, S.K. Temporal and Spatial Patterns of Bartonella Infection in Black-tailed Prairie Dogs (Cynomys ludovicianus). Microb. Ecol. 2008, 56, 373-382. [CrossRef]

72. Kosoy, M.; Murray, M.; Gilmore, R.D.; Bai, Y., Jr.; Gage, K.L. Bartonella strains from ground squirrels are identical to Bartonella washoensis isolated from a human patient. J. Clin. Microbiol. 2003, 41, 645-650. [CrossRef]

73. Welch, D.F.; Carroll, K.C.; Hofmeister, E.K.; Persing, D.H.; Robison, D.A.; Steigerwalt, A.G.; Brenner, D.J. Isolation of a new subspecies, Bartonella vinsonii subsp. arupensis, from a cattle rancher: Identity with isolates found in conjunction with Borrelia burgdorferi and Babesia microti among naturally infected mice. J. Clin. Microbiol. 1999, 37, 2598-2601. [CrossRef] [PubMed]

74. Bai, Y.; Calisher, C.H.; Kosoy, M.Y.; Root, J.J.; Doty, J.B. Persistent Infection or Successive Reinfection of Deer Mice with Bartonella vinsonii subsp. arupensis. Appl. Environ. Microbiol. 2011, 77, 1728-1731. [CrossRef]

75. Lane, R.S.; Mun, J.; Peribáñez, M.A.; Stubbs, H.A. Host-seeking behavior of Ixodes pacificus (Acari: Ixodidae) nymphs in relation to environmental parameters in dense-woodland and woodland-grass habitats. J. Vector Ecol. 2007, 32, 342. [CrossRef]

76. Lane, R.S.; Mun, J.; Peribáñez, M.A.; Fedorova, N. Differences in prevalence of Borrelia burgdorferi and Anaplasma spp. infection among host-seeking Dermacentor occidentalis, Ixodes pacificus, and Ornithodoros coriaceus ticks in northwestern California. Ticks Tick Borne Dis. Dis. 2010, 1, 159-167. [CrossRef] [PubMed]

77. Swei, A.; Ostfeld, R.S.; Lane, R.S.; Briggs, C.J. Impact of the experimental removal of lizards on Lyme disease risk. Proc. Biol. Sci. 2011, 278, 2970-2978. [CrossRef]

78. Lane, R.S.; Mun, J.; Eisen, L.; Eisen, R.J. Refractoriness of the Western Fence Lizard (Sceloporus occidentalis) to the Lyme Disease Group Spirochete Borrelia Bissettii. J. Parasitol. 2006, 92, 691-696. [CrossRef]

79. Salkeld, D.J.; Lagana, D.M.; Wachara, J.; Porter, W.T.; Nieto, N.C. Examining Prevalence and Diversity of Tickborne Pathogens in Questing Ixodes pacificus Ticks in California. Appl. Environ. Microbiol. 2021, 87, e00319-21. [CrossRef] [PubMed]

80. Swei, A.; Bowie, V.C.; Bowie, R.C.K. Comparative genetic diversity of Lyme disease bacteria in Northern Californian ticks and their vertebrate hosts. Ticks Tick Borne Dis. 2015, 6, 414-423. [CrossRef]

81. Mun, J.; Eisen, R.J.; Eisen, L.; Lane, R.S. Detection of a Borrelia miyamotoi sensu lato relapsing-fever group spirochete from Ixodes pacificus in California. J. Med. Entomol. 2006, 43, 120-123. [CrossRef]

82. Sambado, S.; Salomon, J.; Crews, A.; Swei, A. Mixed transmission modes promote persistence of an emerging tickborne pathogen. Ecosphere 2020, 11, e03171. [CrossRef]

83. Cheng, D.; Lane, R.S.; Moore, B.D.; Zhong, J. Host blood meal-dependent growth ensures transovarial transmission and transstadial passage of Rickettsia sp. phylotype G021 in the western black-legged tick (Ixodes pacificus). Ticks Tick Borne Dis. 2013, 4, 421-426. [CrossRef] [PubMed]

84. Cheng, D.; Vigil, K.; Schanes, P.; Brown, R.N.; Zhong, J. Prevalence and burden of two rickettsial phylotypes (G021 and G022) in Ixodes pacificus from California by real-time quantitative PCR. Ticks Tick Borne Dis. 2013, 4, 280-287. [CrossRef]

85. Kwan, J.Y.; Griggs, R.; Chicana, B.; Miller, C.; Swei, A. Vertical vs. horizontal transmission of the microbiome in a key disease vector, Ixodes pacificus. Mol. Ecol. 2017, 26, 6578-6589. [CrossRef] [PubMed]

86. Hunter, D.J.; Torkelson, J.L.; Bodnar, J.; Mortazavi, B.; Laurent, T.; Deason, J.; Thephavongsa, K.; Zhong, J. The Rickettsia Endosymbiont of Ixodes pacificus Contains All the Genes of De Novo Folate Biosynthesis. PLoS ONE 2015, 10, e0144552. [CrossRef] [PubMed] 
87. Bodnar, J.L.; Fitch, S.; Rosati, A.; Zhong, J. The folA gene from the Rickettsia endosymbiont of Ixodes pacificus encodes a functional dihydrofolate reductase enzyme. Ticks Tick Borne Dis. 2018, 9, 443-449. [CrossRef]

88. Kurlovs, A.H.; Li, J.; Cheng, D.; Zhong, J. Ixodes pacificus Ticks Maintain Embryogenesis and Egg Hatching after Antibiotic Treatment of Rickettsia Endosymbiont. PLoS ONE 2014, 9, e104815. [CrossRef]

89. Dumler, J.S.; Barbet, A.F.; Bekker, C.P.; Dasch, G.A.; Palmer, G.H.; Ray, S.C.; Rikihisa, Y.; Rurangirwa, F.R. Reorganization of genera in the families Rickettsiaceae and Anaplasmataceae in the order Rickettsiales: Unification of some species of Ehrlichia with Anaplasma, Cowdria with Ehrlichia and Ehrlichia with Neorickettsia, descriptions of six new species combinations and designation of Ehrlichia equi and 'HGE agent' as subjective synonyms of Ehrlichia phagocytophila. Int. J. Syst. Evol. Microbiol. 2001, 51, 2145-2165. [CrossRef] [PubMed]

90. Rejmanek, D.; Freycon, P.; Bradburd, G.; Dinstell, J.; Foley, J. Unique strains of Anaplasma phagocytophilum segregate among diverse questing and non-questing Ixodes tick species in the western United States. Ticks Tick Borne Dis. 2013, 4, 482-487. [CrossRef]

91. Nieto, N.C.; Foley, J.E. Evaluation of squirrels (Rodentia: Sciuridae) as ecologically significant hosts for Anaplasma phagocytophilum in California. J. Med. Entomol. 2008, 45, 763-769. [CrossRef]

92. Nieto, N.C.; Foley, J.E. Reservoir Competence of the Redwood Chipmunk (Tamias Ochrogenys) for Anaplasma Phagocytophilum. Vector Borne Zoonotic Dis. 2009, 9, 573-577. [CrossRef]

93. Foley, J.E.; Nieto, N.C.; Adjemian, J.; Dabritz, H.; Brown, R.N. Anaplasma phagocytophilum Infection in Small Mammal Hosts of Ixodes Ticks, Western United States. Emerg. Infect. Dis. 2008, 14, 1147-1150. [CrossRef] [PubMed]

94. Nieto, N.C.; Foley, J.E.; Bettaso, J.; Lane, R.S. Reptile infection with Anaplasma phagocytophilum, the causative agent of granulocytic anaplasmosis. J. Parasitol. 2009, 95, 1165-1170. [CrossRef] [PubMed]

95. Dingler, R.J.; Wright, S.A.; Donohue, A.M.; Macedo, P.A.; Foley, J.E. Surveillance for Ixodes pacificus and the tickborne pathogens Anaplasma phagocytophilum and Borrelia burgdorferi in birds from California's Inner Coast Range. Ticks Tick Borne Dis. 2014, 5 , 436-445. [CrossRef]

96. Reubel, G.H.; Kimsey, R.B.; Barlough, J.E.; Madigan, J.E. Experimental Transmission of Ehrlichia equi to Horses through Naturally Infected Ticks (Ixodes pacificus) from Northern California. J. Clin. Microbiol. 1998, 36, 2131-2134. [CrossRef] [PubMed]

97. Kramer, V.L.; Gutierrez, A.G.; Hui, L.T.; Irwin, W.E.; Randolph, M.P.; Vugia, D.J. Detection of the agents of human ehrlichioses in ixodid ticks from California. Am. J. Trop. Med. Hyg. 1999, 60, 62-65. [CrossRef]

98. Richter, P.J.; Kimsey, R.B.; Madigan, J.E.; Barlough, J.E.; Dumler, J.S.; Brooks, D.L. Ixodes pacificus (Acari: Ixodidae) as a Vector of Ehrlichia equi (Rickettsiales: Ehrlichieae). J. Med. Entomol. 1996, 33, 1-5. [CrossRef]

99. Barlough, J.E.; Madigan, J.E.; Turoff, D.R.; Clover, J.R.; Shelly, S.M.; Dumler, J.S. An Ehrlichia strain from a llama (Lama glama) and Llama-associated ticks (Ixodes pacificus). J. Clin. Microbiol. 1997, 35, 1005-1007. [CrossRef]

100. Nieto, N.C.; Leonhard, S.; Foley, J.E.; Lane, R.S. Coinfection of Western Gray Squirrel (Sciurus griseus) and other Sciurid Rodents with Borrelia burgdorferi sensu stricto and Anaplasma phagocytophilum in California. J. Wildl. Dis. 2010, 46, 291-296. [CrossRef]

101. Larson, S.R.; Lee, X.; Paskewitz, S.M. Prevalence of Tickborne Pathogens in Two Species of Peromyscus Mice Common in Northern Wisconsin. J. Med. Entomol. 2018, 55, 1002-1010. [CrossRef]

102. Holden, K.; Boothby, J.T.; Anand, S.; Massung, R.F. Detection of Borrelia burgdorferi, Ehrlichia chaffeensis, and Anaplasma phagocytophilum in Ticks (Acari: Ixodidae) from a Coastal Region of California. J. Med. Entomol. 2003, 40, 534-539. [CrossRef]

103. Dykstra, E.A.; Oltean, H.N.; Kangiser, D.; Marsden-Haug, N.; Rich, S.M.; Xu, G.; Lee, M.K.; Morshed, M.G.; Graham, C.B.; Eisen, R.J. Ecology and Epidemiology of Tickborne Pathogens, Washington, USA, 2011-2016. Emerg. Infect. Dis. 2020, 26, 648-657. [CrossRef]

104. Nwanade, C.F.; Wang, M.; Wang, T.; Yu, Z.; Liu, J. Botanical acaricides and repellents in tick control: Current status and future directions. Exp. Appl. Acarol. 2020, 81,1-35. [CrossRef]

105. Stafford, K.C., III; Williams, S.C.; Molaei, G. Integrated Pest Management in Controlling Ticks and Tick-Associated Diseases. J. Integr. Pest. Manag. 2017, 8, 28. [CrossRef]

106. Sajid, A.; Matias, J.; Arora, G.; Kurokawa, C.; DePonte, K.; Tang, X.; Lynn, G.; Wu, M.-J.; Pal, U.; Strank, N.O.; et al. mRNA vaccination induces tick resistance and prevents transmission of the lyme disease agent. Sci. Transl. Med. 2021, 13, eabj9827. [CrossRef] [PubMed]

107. Richer, L.M.; Brisson, D.; Melo, R.; Ostfeld, R.S.; Zeidner, N.; Gomes-Solecki, M. Reservoir Targeted Vaccine Against Borrelia burgdorferi: A New Strategy to Prevent Lyme Disease Transmission. J. Infect. Dis. 2014, 209, 1972-1980. [CrossRef] [PubMed]

108. Kianersi, S.; Luetke, M.; Wolfe, C.G.; Clark, W.A.; Omodior, O. Associations Between Personal Protective Measures and SelfReported Tick-Borne Disease Diagnosis in Indiana Residents. J. Community Health. 2020, 45, 739-750. [CrossRef]

109. Smith, G.; Wileyto, E.P.; Hopkins, R.B.; Cherry, B.R.; Maher, J.P. Risk factors for lyme disease in Chester County, Pennsylvania. Public Health Rep. 2001, 116 (Suppl. 1), 146-156. [CrossRef]

110. Connally, N.P.; Durante, A.J.; Yousey-Hindes, K.M.; Meek, J.I.; Nelson, R.S.; Heimer, R. Peridomestic Lyme Disease Prevention. Am. J. Prev. Med. 2009, 37, 201-206. [CrossRef] 